\title{
Menthol as a Suggested Fumigant Acaricide against Tetranychus urticae Koch (Actinedida: Tetranychidae) in Green Houses
}

\author{
E. M. Bakr and Aziza M. M. Abou Zaid \\ Plant Protection Research Institute, Agricultural Research Center, Egypt
}

\begin{abstract}
Fumigant toxicity of menthol was investigated against different stages of Tetranychus urticae Koch and two associated predators. Recorded $\mathrm{LC}_{50}$ values were $0.76,0.279$ and $0.269 \mathrm{mg} / \mathrm{l}$ against eggs, protonymphs and adults, respectively. Increase in efficiency was detected with increasing temperature, as $\mathrm{LC}_{50}$ values was decreased from 0.356 to 0.269 and $0.217 \mathrm{mg} / \mathrm{l}$ when temperature increased from $20^{\circ}$ to $25^{\circ}$ and $35^{\circ} \mathrm{C}$; respectively. The two predators, Phytoseiulus persimilis A. H. and Neoseiulus californicus (McGr.) proved to be more tolerant to mentol vapor than T. urticae. Subjecting $T$. urticae proto-nymphs to $\mathrm{LC}_{50}$ of menthol vapor reduced mite productivity as finite rate decreased from 1.37 to 1.29 female per female per day. No significant change was recorded in total proteins, alkaline phosphatase and acid phosphatase between survived-treated and non-treated mites; while significant reduction was recorded in survivedtreated mites in $\alpha$-esterases, $\beta$-esterases and G. S-transferase.
\end{abstract}

Key Words: Menthol, Fumigant, Tetranychus urticae, Phytoseiulus persimilis, Neoseiulus californicus.

\section{INTRODUCTION}

The two spotted spider mite Tetranychus urticae Koch is a serious pest. It attacks vegetables, field and ornamental crops causing sever damage to plants and reduction in yield quality and quantity. It infests many greenhouse plantations causing great problems. Since greenhouses are usually planted with valuable crops, this loss is magnified. Moreover, high-density plantation that usually applied in greenhouses may complicate traditional application of pesticides. High-density plantation also provides shelters for pests which may prevent the pesticides to reach all the pest individuals. So using natural fumigants, might be suitable for controlling red spider mite in greenhouses, because of its safety and capability to reach every point in high density plantation. Fumigant toxicity of several volatile oils was investigated against different pests by many authors (Stamopoulos, 1991; Weaver et al., 1994; Don-Pedro, 1996; Reddy and Singh, 1998; Sammataro et al., 1998 and Badawy et al. 2005). Thus, the aim of the current work was to investigate the fumigant toxicity of menthol against $T$. urticae Koch as one of the main greenhouse pests.

\section{MATERIALS AND METHODS}

\section{Tested mites:}

The original colonies of the two spotted red spider mite Tetranychus urticae Koch and the predators, Phytoseiulus persimilis A. H. and Neoseiulus californicus (McGr.) were supplied from the Acarology Laboratory in Plant Protection Research Institute, Giza, Egypt.

\section{Tested Menthol}

Menthol (Fig. 1) which is well known as the maim aromatic product of genus Mentha, was purchased as white pure crystals. Acetonic solution was prepared to facilitate applying small amounts of menthol.

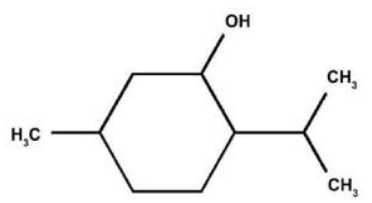

Fig. 1 Menthol structure

\section{Fumigant acaricidal activity:}

The fumigant toxicity of menthol was evaluated against adult females, protonymphs and eggs of $T$. urticae. Also, the effect of menthol on the biological characters of the red spider mite was investigated at $\mathrm{LC}_{50}$ concentration. Airtight jars (5 liters size) were used as a test chambers.

Twenty newly emerged adult females were transferred to the lower surface of mulberry discs (2.5 cm diameter) placed separately on moist cotton wool in small dishes. The dishes were chosen slightly larger than the discs in order to reduce the evaporation of the water in the test jars. The dishes containing mites were fixed on the bottom of the test jars. Series amounts of menthol acetonic solution were transferred to clean Petri dishes using pipette then the dishes were left until acetone was evaporated leaving the intended amount of menthol as a pure layer. Each Petri dish containing the certain amount of menthol was fixed on the bottom of the test jar. Concentrations were calculated as $\mathrm{mg}$. menthol per one liter jar space. Blank treatment was applied as a control. The jars were closed and incubated under constant temperature of 20,25 and $30 \pm 0.5^{\circ} \mathrm{C}$ for $24 \mathrm{~h}$, then the mortality was counted. The activity of menthol vapor was also examined 
against protonymphs using the same procedures then protonymphs were incubated under constant temperature of $25 \pm 0.5^{\circ} \mathrm{C}$ for $24 \mathrm{~h}$, then the mortality was counted.

To investigate the ovicidal activity, ten adult females were transferred each to a mulberry leaf disc $(2.5 \mathrm{~cm})$ placed on wet cotton wool in a Petri dish and left for 24 hours to deposit eggs then removed. Discs with the eggs were placed separately on moist cotton wool in small dishes and subjected to series concentrations of menthol vapor for $24 \mathrm{~h}$, as described above. Treated eggs were then incubated at $25 \pm 0.5{ }^{\circ} \mathrm{C}$ and $60 \% \pm 5$ R.H. for six days till hatching and the percentage of hatchability was determined.

Toxicity of menthol vapor was also examined against two of the T. urticae associated predators, $P$. persimilis and $N$. californicus. Large discs $(5 \mathrm{~cm})$ carried sufficient amount of $T$. urticae eggs were prepared and placed on wet cotton wool in Petri dishes then ten predator adult females were transferred to each disc. Discs with predators were subjected to concentration series of menthol vapor as described above and incubated under constant temperature of $25 \pm 0.5{ }^{\circ} \mathrm{C}$ for $24 \mathrm{~h}$, then the mortality was estimated.

Mortality percentages were corrected by Abbott's formula (1925). $\mathrm{LC}_{50}, \mathrm{LC}_{90}$ and slope values were calculated according to Finney (1971) using "LdP Line"® software.

Changes in the biological aspects of T. urticae were studied after subjecting protonymphs to $\mathrm{LC}_{50}$ concentration (protonymphs $\mathrm{LC}_{50}, 0.29 \mathrm{mg} / \mathrm{l}$ ) for $24 \mathrm{~h}$ as described above. Mortality was recorded then, survived protonymphs were transferred separately each to mulberry leaf disc at $25 \pm 0.5^{\circ} \mathrm{C}$, and its biological aspects were followed up and recorded until death. Data were analyzed using " $\mathrm{t}$ " test in order to examine the differences between survived treated and non- treated mites. Finite rate of increase (a life table parameter) was calculated according to Birch (1948) for both survived treated and non treated mites.

\section{Biochemical analysis:}

Mulberry leaves carried several adult mites were placed on moistened cotton in petri dishes and subjected to $\mathrm{LC}_{50}$ concentration (adults $\mathrm{LC}_{50}, 0.269$ $\mathrm{mg} / \mathrm{l}$ ) for $24 \mathrm{~h}$ in tested jars as described above. Blank treatment was applied as a control. Then, three samples as replicates each of $10 \mathrm{mg}$ alive mite bodies were collected from the survived treated and non-treated mites and frozen until biochemical analysis. Total protein was determined by the method of Bradford (1976). $\alpha$-esterases and $\beta$-esterases were determined according to Van Asperen (1962). Glutathione-S-transferase was measured according to the method described by Habig et al. (1974). Acid phosphatase and alkaline phosphatase were determined according to the method described by Powell and Smith (1954).

\section{RESULTS AND DISCUSSION}

Data in table (1) revealed that menthol vapor was toxic to all tested mite stages while eggs were more tolerant than adults and protonymphs, as $0.76 \mathrm{mg} / \mathrm{l}$ was needed to prevent hatchability of $50 \%$ of eggs. $\mathrm{LC}_{50}$ values were 0.269 and $0.279 \mathrm{mg} / \mathrm{l}$ against adults and protonymphs, respectively. Data in table (2) proved the influence of temperature on the efficiency of menthol vapor against mites. Efficiency increased along with increasing ambient temperature, as $\mathrm{LC}_{50}$ value decreased from 0.356 to 0.269 and $0.217 \mathrm{mg} / \mathrm{l}$ when temperature increased from $20^{\circ}$ to $25^{\circ}$ and $35^{\circ} \mathrm{C}$ respectively, which must be considered in application.

Toxicity of menthol vapor was also studied against two related predators i.e. P. persimilis A. H. and $N$. californicus (Mc Gr.). According to $\mathrm{LC}_{50}$ values and confidential limits, results in table (3) showed that, fortunately $T$. urticae was significantly more susceptible to menthol vapor than the tested predators as $\mathrm{LC}_{50}$ values against $P$. persimilis and $N$. californicus were 0.423 and $0.476 \mathrm{mg} / \mathrm{l}$, respectively. Based on tolerance ratio, the aforementioned predators were 1.57 and 1.77 times tolerant than $T$. urticae, respectively.

Changes in biological aspects of survived mites were determined after subjecting protonymphs to $\mathrm{LC}_{50}$ of menthol vapor $(0.279 \mathrm{mg} / \mathrm{l})$. As found in table (4), survived individuals showed significant elongation in quiescent deutonymph, pre-oviposition and post-oviposition durations compared with non treated mites. The most essential change was the significant reduction in the number of eggs per female, as the treated survived mites laid an average of 39.57 eggs per female; while non treated laid 73.29 eggs per female. The overall effect of treatment: mortality and changes in biological aspects of the survived mites could be expressed in a reduction in finite rate of increase. As shown in table 4 subjecting protonymphs to $\mathrm{LC}_{50}$ reduced finite rate of increase from 1.37 to 1.29 female per female per day.

Changes in total protein and some enzymes were studied in survived mites after subjecting adult females to $\mathrm{LC}_{50}$ of menthol vapor concentration of 
Table (1): Toxicity of menthol vapor on different stages of T. urticae

\begin{tabular}{lccc}
\hline Target stage & $\mathrm{LC}_{50} \mathrm{mg} / \mathrm{l}$ & $\mathrm{LC}_{90} \mathrm{mg} / \mathrm{l}$ & slope \\
\hline Adult & $0.269(0.258-0.287)$ & 0.384 & 8.295 \\
\hline Protonymphs & $0.279(0.267-0.291)$ & 0.416 & 7.364 \\
\hline Egg & $0.760(0.724-0.795)$ & 1.166 & 6.897 \\
\hline
\end{tabular}

Table (2): Toxicity of menthol vapor on T. urticae at different temperatures

\begin{tabular}{lccc}
\hline Temperature & $\mathrm{LC}_{50} \mathrm{mg} / \mathrm{l}$ & $\mathrm{LC}_{90} \mathrm{mg} / \mathrm{l}$ & Slope \\
\hline $35^{\circ} \mathrm{C}$ & $0.217(0.207-0.228)$ & 0.342 & 6.496 \\
\hline $25^{\circ} \mathrm{C}$ & $0.269(0.258-0.287)$ & 0.384 & 8.295 \\
\hline $20^{\circ} \mathrm{C}$ & $0.356(0.338-0.378)$ & 0.603 & 5.599 \\
\hline
\end{tabular}

Table (3): Toxicity of menthol vapor on T. urticae and two related predators

\begin{tabular}{lcccc}
\hline Target mite & $\mathrm{LC}_{50} \mathrm{mg} / \mathrm{l}$ & Tolerance ratio* & $\mathrm{LC}_{90} \mathrm{mg} / \mathrm{l}$ & Slope \\
\hline T. urticae & $0.269(0.258-0.287)$ & 1 & 0.384 & 8.295 \\
\hline P. persimilis & $0.423(0.406-0.444)$ & 1.57 & 0.657 & 6.718 \\
\hline N. californicus & $0.476(0.427-0.537)$ & 1.77 & 0.681 & 8.267 \\
\hline
\end{tabular}

$*$ Tolerance ratio $=\frac{\mathrm{LC}_{50} \text { of compared predator }}{\mathrm{LC}_{50} \text { of reference }(\mathrm{T} \text {. urticae })}$

Table (4). Effect of Menthol vapor at $\mathrm{LC}_{50}$ on the biological aspects of T. urticae.

\begin{tabular}{|c|c|c|c|c|c|c|c|c|c|}
\hline & \multicolumn{7}{|c|}{ Average duration in days } & \multirow[b]{2}{*}{$\begin{array}{c}\text { Eggs } \\
\text { Number }\end{array}$} & \multirow[b]{2}{*}{$\begin{array}{c}\text { Finite rate of } \\
\text { increase }\end{array}$} \\
\hline & $\begin{array}{l}\text { Pre-treatment } \\
\text { duration }\end{array}$ & $\begin{array}{c}\text { Q. } \\
\text { Proto-nymph }\end{array}$ & Deuto-nymph & $\begin{array}{c}\text { Q. } \\
\text { Deuto-Nymph }\end{array}$ & Pre ov. & Ov. & Post Ov. & & \\
\hline Treated & \multirow{2}{*}{7.24} & 0.91 & 1.08 & 1.08 & 1.09 & 13.14 & 0.86 & 39.57 & 1.29 \\
\hline Control & & 0.86 & 1.07 & 0.56 & 0.63 & 13.38 & 3.8 & 73.29 & 1.37 \\
\hline $\mathrm{P}$ & & 0.851 & 0.940 & $0.004^{* *}$ & $0.054^{*}$ & 0.941 & $0.044^{*}$ & $0.022^{* * *}$ & \\
\hline
\end{tabular}

Q.: Quiescent, Ov.: oviposition, *: significant $0.95, * *$ : significant $0.99, \mathrm{P}:$ probability of $\mathrm{T}$

Table (5). Intensity of total proteins and some enzymes in the mites survived from $\mathrm{LC}_{50}$ of menthol vapor and non treated mites

\begin{tabular}{ccccccc}
\hline & total proteins $^{(1)}$ & $\alpha$-esterases $^{(2)}$ & -esterases $^{(3)}$ & Alkaline phosphatase $^{(4)}$ & cid phosphatase $^{(5)}$ & G. S-transferase $^{(6)}$ \\
\hline Control & 23.215 & 12.985 & 4.131 & 2.527 & 902.67 & 42.677 \\
\hline Treated & 24.474 & 9.337 & 3.815 & 2.635 & 1044.83 & 16.575 \\
\hline $\mathrm{P}$ & 0.52529 & $0.00078^{* *}$ & $0.00713^{* *}$ & 0.73153 & 0.09925 & $0.00029^{* *}$ \\
\hline
\end{tabular}
(1): $\mathrm{mg} / \mathrm{g} . \mathrm{b} . \mathrm{wt}$;
(2): $\mathrm{mg} \alpha$-naphthol/ min/ g.b. wt;
(3): mg $\beta$-naphthol/ min/ g.b. wt;
(4): U/g.b.wt.;
(5): $\mathrm{U} * 10^{3}$ /g.b.wt.; (6): mmole substrate conjugated/ $\mathrm{min} /$ g.b. wt. $\quad * *$ : significant 0.99 , P: probability of T.

(0.269 mg/l). Results in table (5) showed that no significant change was recorded in total proteins, alkaline phosphatase and acid phosphatase between survived treated and non-treated mites. Concerning other enzymes, a significant reduction was recorded in survived-treated mites compared with non-treated mites. $\alpha$-esterases reduced from 12.985 to $9.337 \mathrm{mg}$ $\alpha$-naphthol $/ \mathrm{min} /$ g.b. wt. $\beta$-esterases reduced from 4.131 to $3.815 \mathrm{mg} \beta$-naphthol/ min/ g.b. wt. While G. S-transferase recorded the most considerable reduction from 42.677 to 16.575 mmole substrate conjugated/ $\mathrm{min} /$ g.b. wt.

Toxicity of menthol was previously proved, against different pests; contact and vapor toxicity were proved by Aggarwal et al., 2001 against four storage insects and against Tyrophagus longior mite by Perrucci, 1995. Also fumigant toxicity of menthol was reported by Erler, and Tunç 2005 against Tetranychus cinnabarinus (Bois) in green house.

\section{REFERENCES}

Abbott, W.S. 1925. A method of computing the effectiveness of an insecticide. J. Econ. Entomol., 18, 265-267.

Aggarwal, K.K.; Tripathi, A.K.; Ahmad, A.; Prajapati, V.; Verma, N. and Kumar, S. 2001. 
Toxicity of 1-menthol and its derivatives against four storage insects. Int. J. Trop. Insect Sci., 21 (3): 229-235.

Badawy, H. M. A.; Barakat, A. A.; Farrag, A. M. I. and Bakr, E. M. 2005. Biological activity of several essential oils against Tetranychus urticate Koch. (Bull. Ent. Soc. Egypt, Econ. Ser., 31, 69-78).

Birch, L. C. 1948. The intrinsic rate of natural increase of an insect population. J. Anim. Ecol., 17: 15-26.

Bradford, M. M. 1976. A rapid and sensitive method for the quantitation of microgram quantities of protein utilizing the principle of protein-day binding. Anal. Biochem., 72 :248-258.

Don-Pedro, K. N. 1996. Fumigant toxicity of citruspeel oils against adult and immature stages of storage insect pests. Pestic. Sci., 47, 213-223.

Erler, F. and Tunç, W. 2005. Monoterpenoids as fumigants against greenhouse pests: toxic, development and reproduction-inhibiting effects. Journal of Plant Diseases and Protection, 112 (2): 181-192.

Finney, D.J. 1971. Probit Analysis. Cambridge Univ. Press, pp 333.

Habig, W. H.; Pabst, M. J. and Jakoby, W. B. 1974. Glutathione-S-transferase the first enzymatic step in mercapturic acid formation. J. Boil. Chem., 249: 7130-7139.

Perrucci, Stefania 1995. Acaricidal activity of some essential oils and their constituents against
Tyrophagus longior, a mite of stored food. J. Food Protect., 58 (5): 560-563.

Powell, M. E. A. and Smith, M. J. H. 1954. The determination of serum acid and alkaline phosphatase activity with 4-aminoantipyrien. J. Clin. Pathol., 7 : 245-248.

Reddy, A. V. and Singh, R. P. 1998. Fumigant toxicity of neem (Azadirachta indica A. Juss.) seed oil volatiles against pulse beetle, Callosobruchus maculatus Fab. (Col., Bruchidiae). J. Appl. Ent., 122: 607-611.

Sammataro, D.; Drgrandi-Hoffman, G.; Needham, G. and Wardell, G. 1998. Some volatile plant oils as potential control agents for varroa mites (Acari: varroidae) in honey bee colonies (hymenoptra: apidae) Am. Bee J., 138: 681-685.

Stamopoulos, D. C. 1991. Effect of four essential oil vapours on the oviposition and fecundity of Acanthoscelides obtecus (Say) (Coleoptra: Bruchidae): laboratory evaluation. J. Stored Prod. Res., 27: 199-203.

Van Asperen, K. 1962. A study of house fly esterase by means of sensitive colourimetric method. $\mathrm{J}$. Insect Physiol., 8: 401-416.

Weaver, D. K.; Dunkel, F. V.; Potter, R. C. and Ntezurubanza, L. 1994. Contact and fumigant efficacy of powdered and intact Ocimum canum Sims (lamiales: lamiaceae) against Zabrotes subfasciatus (Boheman) adults (coleoptra: Bruchidae). J. stored Prod. Res., 30: 243-252. 